\title{
Influence of plant growth regulators and salicylic acid on the production of some secondary metabolites in callus and cell suspension culture of Satureja sahendica Bornm.
}

\author{
Sarieh TARIGHOLIZADEH ${ }^{1}$, Rouhollah MOTAFAKKERAZAD ${ }^{1,2}$, Morteza KOSARI-NASAB ${ }^{1,3}$, Ali \\ MOVAFEGHI ${ }^{1}$, Sakineh MOHAMMADI ${ }^{1}$, Mohsen SABZI ${ }^{4}$, Amir-Hossein TALEBPOUR ${ }^{5}$
}

Received April 23, 2018; accepted October 19, 2021. Delo je prispelo 23. aprila 2018, sprejeto 19. oktobra 2021

\begin{abstract}
Influence of plant growth regulators and salicylic acid on the production of some secondary metabolites in callus and cell suspension culture of Satureja sahendica Bornm.

Abstract: The impact of combinations of plant growth regulators (PGRs) on callus culture of Satureja sahendica Bornm. was investigated. In nodal explants, the response of secondary metabolite production to different concentrations of PGRs was analyzed regarding the presence and absence of polyvinylpyrrolidone (PVP). The explants were cultured on MS media in presence of auxins (2,4-dichlorophenoxyacetic acid and naphthylacetic acid) and cytokinins (thidiazuron and kinetin); which were used in equal concentrations of 0.5 , 1 , and $2 \mathrm{mg} \mathrm{l}^{-1}$. The treatment of $2 \mathrm{mg} \mathrm{l}^{-1} 2,4-\mathrm{D}+2 \mathrm{mg} \mathrm{l}^{-1} \mathrm{Kin}$ (MD3) led to the highest production of total phenolics (4.303 $\left.\pm 0.449 \mathrm{mg} \mathrm{GAE}^{-1}\right)$ and flavonoids $(24.903 \pm 7.016 \mathrm{mg} \mathrm{QE}$ $\mathrm{g}^{-1}$ ). Moreover, the effect of salicylic acid (SA) on the production of secondary metabolites in cell suspension culture of Satureja sahendica was evaluated. The cell suspension culture was established by culturing the nodal-derived friable callus in the liquid medium containing different concentrations of SA $(0,100,150,200 \mu \mathrm{M})$. An inverse relationship exists between the fresh mass and secondary metabolites contents. In addition, there was a significant difference among concentrations of SA in the production of total phenolics and flavonoid compounds. SA enhances secondary metabolites production and decreases cell fresh mass.

Key words: Satureja sahendica; callus induction; cell suspension culture; secondary metabolites; growth regulators; salicylic acid
\end{abstract}

Vpliv rastlinskih rastnih regulatorjev in salicilne kisline na tvorbo nekaterih sekundarnih metabolitov $\mathrm{v}$ kalusu in suspenziji celične kulture vrste šetraja Satureja sahendica Bornm.

Izvleček: Preučevan je bil vpliv kombinacije rastlinskih rastnih regulatorjev (PGRs) na kulturo kalusa vrste šetraja $\mathrm{Sa}$ tureja sahendica Bornm. V nodijskih izsečkih je bil preučevan odziv tvorbe sekundarnih metabolitov na različne koncentracije PGRs glede na prisotnost in odsotnost polivinilpirolidona (PVP). Izsečki so bili gojeni v MS gojišču v prisotnosti auksinov (2,4-diklorofenoksiocetna kislina in naftilocetna kislina) in citokininov (tidiazuron in kinetin), ki so bili uporabljeni v enakih koncentracijah 0,$5 ; 1$, in $2 \mathrm{mg} \mathrm{l}^{-1}$. Obravnavanje $2 \mathrm{mg} \mathrm{l}^{-1} 2,4-\mathrm{D}$ $+2 \mathrm{mg} \mathrm{l}^{-1} \mathrm{Kin}$ (MD3) je vodilo k največji tvorbi celokupnih fenolov $\left(4,303 \pm 0,449 \mathrm{mg} \mathrm{GAE} \mathrm{g}^{-1}\right)$ in flavonoidov $(2,903 \pm 7,016$ $\left.\mathrm{mg} \mathrm{QE}^{-1}\right)$. Dodatno je bil ovrednoten učinek salicilne kisline (SA) na tvorbo sekundarnih metabolitov v kulturi suspenzije celic šetraja. Kultura suspenzije celic je bila vzpostavljena $\mathrm{z}$ gojenjem rahlega kalusa, pridobljenga iz nodijskih izsečkov $\mathrm{v}$ tekočem mediju, ki je vseboval različne koncentracije SA (0, $100,150,200 \mu \mathrm{M})$. Pojavilo se je obratno sorazmerje med svežo maso in vsebnostjo sekundarnih metabolitov. Med različnimi koncentracijami salicilne kisline ni bilo opaziti značilnih razlik na tvorbo celokupnih fenolov in flavonoidov. Salicilna kislina vzpodbuja tvorbo sekundarnih metabolitov in zmajšuje svežo maso celične kulture.

Ključne besede: Satureja sahendica; indukcija kalusa; kultura suspenzije celic; sekundarni metaboliti; rastni regulatorji; salicilna kislina

\footnotetext{
Department of Plant Sciences, Faculty of Natural Sciences, University of Tabriz, Tabriz, Iran

2 Corresponding author, email: rmotafakker@tabrizu.ac.ir

3 Drug Applied Research Center, Tabriz University of Medical Sciences, Tabriz, Iran

4 Ahar Faculty of Agriculture and Natural Resources, University of Tabriz, Iran

5 East Azerbaijan Research Center for Agriculture and Natural Resources, Tabriz, Iran
} 


\section{INTRODUCTION}

Satureja is an extra-large genus of Lamiaceae: Nepetoideae and comprises about 200 species of often aromatic shrubs and herbs distributed in Asia, the Mediterranean region, and North America. The flora of Iran possesses 14 species of this genus, 9 of which are endemic. The members of this genus is widely found in mountainous areas in Iran (Rechinger, 1982; Jamzad, 1996; Mozaffarian, 1996). Many species of the genus are traditionally used for curing diseases such as wounds, muscle pains, diarrhea, nausea, infections, and gastroenteritis (Hadian et al., 2012). Like many members of Lamiaceae, Satureja species are very rich in secondary metabolites such as flavonoids, phenolics diterpenes, and phenolic acids, and therefore they have gained attention from researchers for their applications in various fields (Ghotbabadi et al., 2012).

Satureja sahendica Bornm., locally known as "Marze-Sahandi", is an endemic species of Satureja in Iran and is distributed in Northwestern and Western regions in East Azerbaijan, Zanjan, and Kurdistan provinces (Mozaffarian, 1993). This plant is a perennial, branched, bushy, aromatic, and late flowering herb (Ghahreman, 1988, 1993). Literature reviews show that 39 components were identified in the oil of S. sahendica and the main constituents of the essential oils were thymol (19.6 - $41.7 \%)$, p-cymene (32.5 - $54.9 \%)$, and $\gamma$-terpinene (1.0 - $12.8 \%)$ (Sefidkon et al., 2004; Hassanpouraghdam et al., 2009). In recent years, the presence of several antioxidant compounds in this plant was reported. Furthermore, some flavonoids such as derivatives of diosmetin, quercetin, luteolin, and apigenin were found in this species (Saeidnia et al., 2011; Hadjmohammadi et al., 2012).

Although a significant amount of research has been done on the composition of the oil and the chemical and physical characteristics as well as medicinal properties of this species, tissue culture-related activities have been limited to some species of Satureja. Actually, major work has not been done to analyze Satureja sahendica metabolites. For instance, a study evaluated antimicrobial and antioxidant activities of the essential oil from aerial parts of Satureja hortensis L. via callus culture (Güllüce, 2003). Moreover, the production and optimization of rosmarinic acid (an important phenolic acid) were investigated in the callus culture of $S$. hortensis (Tepe \& Sokmen, 2007).

Development of appropriate conditions and techniques for the production of phenolic compounds is required due to their medical and commercial values including a range of biological activities such as antibacterial, anti-viral, and anti-cancer (Taveira et al.,
2010). Previous researches illustrated that plant in vitro culture is a suitable technique for the production of valuable metabolites in most plants, and the stimulants could be applied as physical and chemical stress for the production of these metabolites as one of the most successful strategies (Ravishandera et al., 1999; Dörnenburg \& Knorr, 1995). The production and accumulation of secondary metabolites in plants is known as a part of the defense response against pathogenic attacks, which could be triggered and activated by growth regulators and elicitors (Zhong et al., 1996; Wang et al., 2004; AlSane et al., 2005; Shilpashree \& Rai, 2009). Elicitors, either biological or non-biological compounds, increase the secondary metabolites production by activating the genes involved in the biosynthesis of these compounds (Neumann et al., 2009). Salicylic acid (SA) or 2-hydroxybenzoic acid, a type of plant phenolics, is an effective inducer of genes involved in plants' defense system. Therefore, SA can effectively induce the enhancement of secondary metabolites production such as alkaloids, terpenoids, phenolics, and phytoalexins (Vlot, 2008). It has been reported that the production of taxol in the suspension culture of Taxus baccata L. was considerably increased by SA compared to the control (Khosroushahi, 2006). Salicylic acid caused also a significant increase in the production of alkaloids in the hairy root culture of Brugmansia x candida Pers. (Alvarez et al., 2000) and it likewise enhanced the synthesis of total flavonoids in the suspension culture of Andrographis paniculata (Burm.f.) Nees (Mendhulkar, 2013). The application of SA for the production of curcumin in the Catharanthus roseus (L.) G.D on cell culture has been also reported (Matkowski, 2008).

Due to lack of a basic investigation on plant tissue culture in S. sahendica, and after our last research on the in vitro production of secondary metabolites of Lallemantia iberica (M.Bieb.) Fisch. \& C.A.Mey. as a member of Lamiaceae (Pourebad et al., 2015), we became interested to work on tissue and cell culture of this plant species. Correspondingly, based on our preliminary accomplished work (Tarigholizadeh et al., 2015), we aimed to study callus and cell suspension culture conditions and determination of total phenolic and flavonoid compounds in S. sahendica using different concentrations and combinations of growth regulators and SA. The present work focuses on the secondary metabolites production of $S$. sahendica via callus and cell suspension cultures and highlights the potential of this plant species for further pharmaceutical researches. 


\section{MATERIALS AND METHOD}

\subsection{PLANT MATERIAL}

Seeds of Satureja sahendica Bornm. were obtained from the Botanical garden of East- Azerbaijan province in Iran, and were surface-sterilized with $70 \%$ ethanol for 1 minute, rinsed once with water, followed by 10 minutes immersion in $1 \%$ formaldehyde plus a few drops of $80 \%$ Tween and interspersed with washings in sterile distilled water. After that, seeds were sterilized with commercial hypochlorite solution (20\%) for 10 minutes. After 3 rinses with sterile distilled water, the seeds were treated with giberellic acid $\left(200 \mathrm{mg} \mathrm{l}^{-1}\right.$ for $15 \mathrm{~min}$ ) for the elimination of the dormancy problem (Tarigholizadeh et al., 2015). Then, the seeds were cultivated on a hormone-free MS basal medium (Murashige \& Skoog, 1962).

\subsection{CALLUS INDUCTION}

Callus culture was started by nodal explants of in vitro germinated 30-days-old seedlings of S. sahendica and were cultured on MS medium supplemented with different combinations of 2,4-D (2,4-dichlorophenoxyacetic acid) and kin (kinetin) as well as NAA (naphthylacetic acid) and TDZ (thidiazuron) in different concentrations as presented in Table 1. In order to examine the effect of polyvinylpyrrolidone (PVP) on callus growth and secondary metabolites production, we aimed to apply a distinct set of experiments with the same PGRs and their combinations mentioned above and 400 $\mu$ PVP. Therefore, there were two types and series of media (each medium: $250 \mathrm{ml}$ ) for callus induction: with the presence of PVP (PVP+) and absence of PVP (PVP-). The $\mathrm{pH}$ value of all media were adjusted at 5.6 - 5.8 with $1 \mathrm{~N} \mathrm{NaOH}$ prior to adding of agar $\left(8.0 \mathrm{~g} \mathrm{l}^{-1}\right)$ and subsequently they were autoclaved for 15 minutes $\left(121{ }^{\circ} \mathrm{C}, 104 \mathrm{kPa}\right)$ and dispensed into glass jars (each containing $250 \mathrm{ml}$ ). Three glass jars containing seven explants and each were cultured per treatment. For control groups, we used MS with and without PVP. All cultures were maintained in the growth room $16 \mathrm{~h}$ light (40 $\mu \mathrm{mol} \mathrm{m} \mathrm{m}^{-2} \mathrm{~s}^{-1}$ white cool fluorescence) and $8 \mathrm{~h}$ dark at $23 \pm 2^{\circ} \mathrm{C}$ for four weeks. Then, callus samples were subcultured once and four weeks later, were collected for evaluation of the following parameters: callogenesis percentage, morphological traits and total phenolic and flavonoid contents.
Table 1: List of MS media supplemented with different growth regulators for callus induction

\begin{tabular}{ll}
\hline Growth regulators $\left(\mathrm{mg} \mathrm{l}^{-1}\right)$ & Media $(-P V P$ or + PVP) \\
\hline NAA $0.5+$ TDZ 0.5 & MN1 \\
NAA $1.0+$ TDZ 1.0 & MN2 \\
NAA $2.0+$ TDZ 2.0 & MN3 \\
2,4-D $0.5+$ Kin 0.5 & MD1 \\
2,4-D 1.0 + Kin 1.0 & MD2 \\
2,4-D 2.0 + Kin 2.0 & MD3 \\
\hline
\end{tabular}

\subsection{ESTABLISHMENT AND MAINTENANCE OF CELL SUSPENSION CULTURE}

In order to callogenesis for establishing cell suspension culture, callus induction was carried out in the same above-mentioned way. However, the exerted PGRs were only 2,4-D and Kin with two different concentrations of each $\left(0.5,1 \mathrm{mg} \mathrm{l}^{-1}\right)$. To establish suspension culture, $0.5 \mathrm{~g}$ of healthy and two-month-age callus tissues were transferred to $50 \mathrm{ml}$ of MS medium with mentioned PGRs compounds without agar and were kept on shakers at $110 \mathrm{rpm}$ (revolutions per minute) and $25{ }^{\circ} \mathrm{C}$ in the dark. Cultured samples were subcultured once per three weeks to establish cell lines. In each subculture, $5 \mathrm{ml}$ of medium containing cells was added to $45 \mathrm{ml}$ of new medium with the same PGRs. Based on previous studies and our preliminary researches, different concentrations of SA were chosen and their effects on cultured cells and tissues were examined. For this propose, $5 \mathrm{ml}$ of cell culture medium was transferred to $45 \mathrm{ml}$ MS liquid medium containing 0 (control), 100,150 and $200 \mu \mathrm{M}$ concentrations of sterilized SA. Samples were then placed on a shaker $\left(110 \mathrm{rpm}, 25^{\circ} \mathrm{C}\right)$ in darkness for three weeks. Finally, the samples were collected to examine the influence of different concentrations of SA on growth and secondary metabolites production.

\subsection{DETERMINATION OF TOTAL PHENOLIC AND FLAVONOID CONTENTS}

Callus cultures derived from nodal segments using the different combinations of growth regulators were dried in oven at $35{ }^{\circ} \mathrm{C}$ for $30 \mathrm{~h}$. Then, $0.5 \mathrm{~g}$ of dried callus from each sample was mixed with methanol in a small glass tube and were put at $25{ }^{\circ} \mathrm{C}$ for $40 \mathrm{~h}$. This procedure was done for each treatment and extracts and they were centrifuged at $16300 \mathrm{x}$ g for 15 minutes. The supernatant was separated for measurement of 
total phenolics and flavonoids content. In addition, in cell suspension culture, cell growth was determined by measuring the fresh mass (due to low dry mass in cell suspension culture) and total cell extract was prepared to measure total phenolics and flavonoids contents.

For the determination of total phenolics content in callus and cell culture, Folin-Ciocalteu reagent was used (Singleton et al., 1999). In brief, $100 \mu \mathrm{l}$ of each extract was combined with $2.5 \mathrm{ml}$ of distilled water, and then mixed thoroughly with $100 \mu \mathrm{l}$ of Folin-Ciocalteu reagent. After 6 minutes, $150 \mu \mathrm{l}$ of $20 \%$ (w/v) sodium carbonate was added and the solution was left at room temperature for 30 minutes in the dark. The absorbance of the reaction mixtures was measured at $650 \mathrm{~nm}$. The results were expressed in the form of gallic acid equivalents (GAE) per gram of dry mass.

The total flavonoids content in callus and cell culture was estimated by using the aluminum chloride colorimetric method (Chang et al., 2002). A quantity of $500 \mu \mathrm{l}$ of each sample solution was combined with $2.5 \mathrm{ml}$ of distilled water and subsequently with $150 \mu \mathrm{l}$ of $5 \%$ sodium nitrite $\left(\mathrm{NaNO}_{2}\right)$ solution, after $6 \mathrm{~min}$ of mixing, $300 \mu \mathrm{l}$ of $10 \%$ aluminum chloride $\left(\mathrm{AlCl}_{3}\right)$ was added and then allowed to stand 5 minutes, followed by adding $1000 \mu \mathrm{l}$ of $1 \mathrm{M} \mathrm{NaOH}$ solution to the mixture. The obtained solution was thoroughly mixed, after which the absorbance was determined at $510 \mathrm{~nm}$. The results were expressed as mg quercetin equivalents (QE) per gram of dry mass.

\subsection{STATISTICAL ANALYSIS}

All experiments were performed in a completely randomized design. Each treatment was comprised of three replicates. A one-way analysis of variance (ANOVA) was applied to statistically analyze the data that was obtained from callus tissues and the means were compared by Duncan's Multiple Range Tests (DMRT). IBM SPSS statistic ver. 22 was used to determine the significance at $p \leq 0.05$.

\section{RESULTS AND DISCUSSION}

\subsection{CALLUS INDUCTION AND MORPHOLOGY}

Table 2 shows the effects of PGRs on S. sahendica nodal explants cultured on MS medium, displaying the callogenetic and morphologic properties of callus tissues. Shoot formation was also observed during callus growth, and therefore the percentage of produced organs by nodal explants was reported (in relation to
PVP). First callus tissues appeared on nodal explants after 10 days of culture. However, callogenesis in the combination of 2, 4-D + Kin occurred one week later. Callus tissues covered almost all the explants surface within 30 days. Green-compact and yellowish greenfriable callus tissues were formed by NAA+TDZ and 2, 4-D + Kin groups, respectively. In treatments with 2, 4-D, and Kin, shoot formation was not observed and high concentrations of these PGRs resulted in a low callogenesis efficiency (Table 2). As expected, the absence of PGRs in MS and MS + PVP media (control groups) showed a strong shooting response without production of any callus tissues, and therefore this group was excluded from further examination (data not shown). The PVP application with growth regulators induced a general increase in callogenesis (Table 2). Actually, the addition of PVP to the medium was effective in overcoming the browning of the culture medium and promoted callogenesis. PVP hydrogen bonds are able to absorb phenolic substances, and thus reduce their amount in medium. These substances are released from tissues and cells into the surrounding medium and their accumulation may result in decreased rates of growth and development of cultured materials (Saxena et al., 1986; Leyser et al., 2003). Similar effects of PVP were also reported by Saxena et al. (1999) and Ogita et al. (2001) in a bamboo (Dendrocalamus strictus (Roxb.) Nees) tissue culture. In the current study, S. sahendica nodal material was used to test PVP and PGRs effects on in vitro cultured tissues. As it is shown, NAA + TDZ promoted callus production with significant shoot formation. Previous reports revealed that TDZ alone and in combination with NAA strongly promoted compact-green nodular callus and shoot formation in shrubs (Tarigholizadeh et al., 2015, Al-juboory et al., 1998; Murthy, 1998; Thiruvengadam \& Chung, 2015).

\subsection{THE EFFECT OF PGRS ON CALLUS TISSUES GROWTH}

Our experiments revealed that callus growth of $S$. sahendica was strongly affected by type, combination, and different concentrations of PGRs (Table 3). Statistically significant differences were found between 2,4$\mathrm{D}+$ Kin and NAA + TDZ treatments. Moreover, callus growth was also affected by the presence of PVP. PVP exerted its positive effects on both fresh and dry mass of callus tissues in PVP+ media (Fig. 1 and Table 3). As shown in Figure 1 and Table 3, we obtained the highest fresh mass from MN3 and MN1 in PVP- and $\mathrm{PVP}+$ media, respectively. However, there were no significant differences among the different concentrations 
Table 2: Effect of different combinations of PGRs on callus induction and morphology in presence (PVP+) or absence (PVP-) of polyvinylpyrrolidone

\begin{tabular}{|c|c|c|c|c|c|}
\hline \multirow[b]{2}{*}{ Media } & \multicolumn{2}{|l|}{ Callogenesis \% } & \multirow{2}{*}{$\begin{array}{l}\text { Callus tissues morphology } \\
\text { PVP } \pm\end{array}$} & \multicolumn{2}{|c|}{ Shoot formation $\%$} \\
\hline & $\mathrm{PVP}+$ & PVP- & & $\mathrm{PVP}+$ & PVP- \\
\hline MN1 & $100 \pm 0.00^{\mathrm{a}}$ & $90.48 \pm 9.52^{\mathrm{ab}}$ & Green, Compact & $42.86 \pm 0.00^{\mathrm{b}}$ & $76.19 \pm 4.76^{b}$ \\
\hline MN2 & $95.24 \pm 4.763^{\mathrm{b}}$ & $100 \pm 0.00^{a}$ & Green, Compact & $71.43 \pm 0.00^{\mathrm{a}}$ & $90.47 \pm 4.76^{\mathrm{a}}$ \\
\hline MN3 & $100 \pm 0.00^{\mathrm{a}}$ & $100 \pm 0.00^{\mathrm{a}}$ & Green, Compact & $52.38 \pm 12.60^{\mathrm{b}}$ & $71.43 \pm 8.25^{b}$ \\
\hline MD1 & $100 \pm 0.00^{\mathrm{a}}$ & $100 \pm 0.00^{\mathrm{a}}$ & Yellowish-Green, Friable & $0.00 \pm 0.00^{c}$ & $0.00 \pm 0.00^{c}$ \\
\hline MD2 & $71.43 \pm 0.00^{c}$ & $90.48 \pm 9.52^{\mathrm{ab}}$ & Yellowish-Green, Friable & $0.00 \pm 0.00^{c}$ & $0.00 \pm 0.00^{c}$ \\
\hline MD3 & $90.47 \pm 4.763^{\mathrm{b}}$ & $66.67 \pm 17.17^{b}$ & Yellowish-Green, Friable & $0.00 \pm 0.00^{c}$ & $0.00 \pm 0.00^{c}$ \\
\hline
\end{tabular}

Data within the two columns (PVP-/PVP+) of each growth parameter, followed by different letters are significantly different at $p \leq 0.05$. The data are presented as means $\pm \mathrm{SE}(\mathrm{n}=3)$

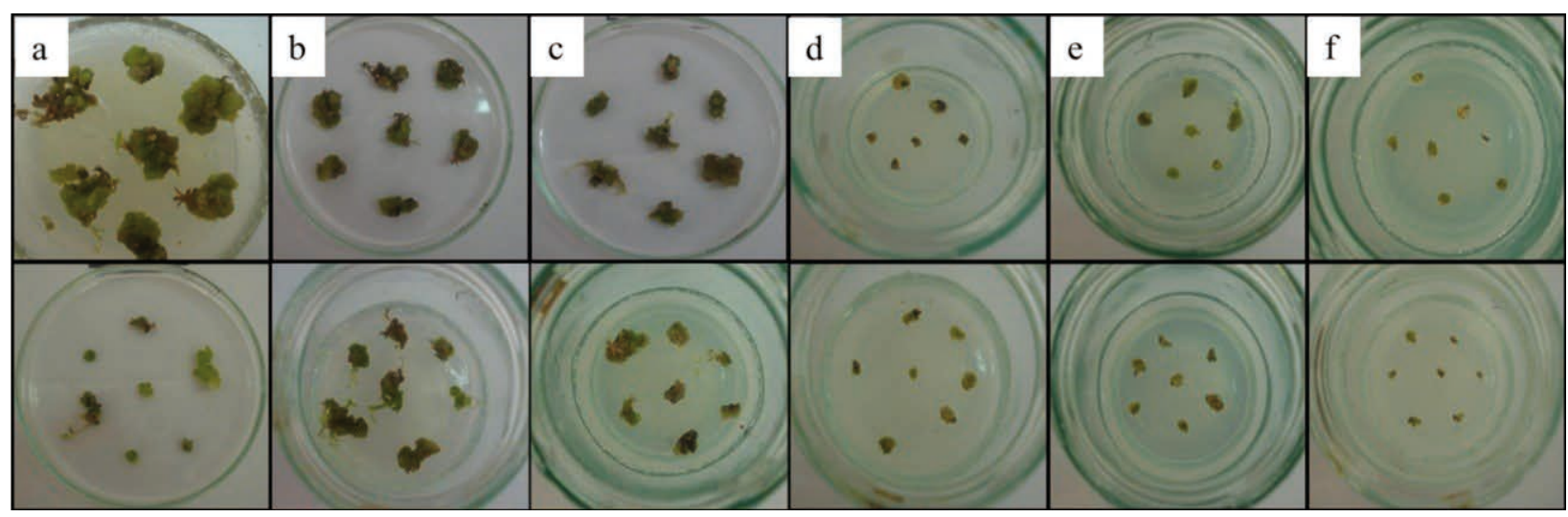

Figure 1: S. sahendica callus tissues grown on MS medium in the presence (upper row) and in the absence (lower row) of PVP and with the addition of PGRs. a (MN1), b (MN2), c (MN3), d (MD1), e (MD2), f (MD3)

Table 3: Effect of different combinations of PGRs on callus tissues growth in MS PVP- and PVP+ medium

\begin{tabular}{lllll}
\hline & Fresh mass $(\mathrm{mg})$ & \multicolumn{2}{l}{ Dry mass $(\mathrm{mg})$} \\
\cline { 2 - 5 } Media & PVP+ & PVP- & PVP+ & PVP- \\
\hline MN1 & $1.969 \pm 0.535^{\mathrm{a}}$ & $0.848 \pm 0.162^{\mathrm{ab}}$ & $0.118 \pm 0.023^{\mathrm{a}}$ & $0.066^{\mathrm{a}} \pm 0.014^{\mathrm{ab}}$ \\
MN2 & $1.966 \pm 0.393^{\mathrm{a}}$ & $1.354 \pm 0.435^{\mathrm{a}}$ & $0.130 \pm 0.022^{\mathrm{a}}$ & $0.096^{\mathrm{a}} \pm 0.031^{\mathrm{a}}$ \\
MN3 & $1.460 \pm 0.197^{\mathrm{a}}$ & $1.384 \pm 0.155^{\mathrm{a}}$ & $0.099 \pm 0.017^{\mathrm{a}}$ & $0.094 \pm 0.011^{\mathrm{a}}$ \\
MD1 & $0.287 \pm 0.028^{\mathrm{b}}$ & $0.477 \pm 0.086^{\mathrm{bc}}$ & $0.026 \pm 0.001^{\mathrm{b}}$ & $0.047 \pm 0.014^{\mathrm{abc}}$ \\
MD2 & $0.334 \pm 0.026^{\mathrm{b}}$ & $0.256 \pm 0.056^{\mathrm{bc}}$ & $0.026 \pm 0.002^{\mathrm{b}}$ & $0.022^{\mathrm{c}} \pm 0.003^{\mathrm{bc}}$ \\
MD3 & $0.160 \pm 0.02^{\mathrm{b}}$ & $0.140 \pm 0.028^{\mathrm{c}}$ & $0.020 \pm 0.004^{\mathrm{b}}$ & $0.011 \pm 0.004^{\mathrm{c}}$ \\
\hline
\end{tabular}

Different letters within two columns (PVP-/PVP+) of each growth parameter represent significant differences among treatments at $p \leq 0.05$. The data are presented as means $\pm S E(n=3)$

of growth regulators within a group. The highest dry mass was achieved by MN2 in both PVP- and PVP+ media. Once again, there were no significant differences within a group. As an obtained result, the presence of NAA and TDZ in the medium improved the growth of callus tissues. These result regarding all other examined growth parameters reinforced the findings of our previ- ous work where the effects of the PGRs and PVP were observed on callus relative growth rate (RGR) (Tarigholizadeh et al., 2015). Correspondingly, Ali et al. (2013) reported that NAA in combination with TDZ was more effective for callus formation of Artemisia absinthium L. than other combinations of PGR. They achieved the highest callogenesis frequency $(83.3 \%)$ and maximum 
callus biomass (FW: $132 \mathrm{gl}^{-1}$ ) on MS medium supplemented with $1 \mathrm{mg} \mathrm{l}^{-1} \mathrm{NAA}+1 \mathrm{mg} \mathrm{l}^{-1} \mathrm{TDZ}$. Similarly, the dry mass showed the highest amount in $1 \mathrm{mg} \mathrm{l}^{-1}$ of both NAA and TDZ in callus of S. sahendica, although varying this concentration resulted in the reduction of dry mass. Previously, decrease in callogenic responses or mass production has been observed using 2,4-D in combination with Kin (Jeong et al., 2007; Hakkim et al., 2007; Johnson et al., 2011; Walla Abdelazeez et al., 2017). Thus, combination of 2, 4-D and Kin is not appropriate for the induction of callus tissues in nodal explants of $S$. sahendica compared with NAA + TDZ group.

\subsection{THE EFFECT OF PVP AND PGRS ON PHENO- LIC COMPOUNDS PRODUCTION IN CALLUS TISSUES}

The present study shows that total phenolics concentration depends on the type and combination of PGRs in the culture medium. Accumulation of phenolic compounds indicated differences between two groups of growth regulators used in this study. As can be seen in Figures 2 and 3, media containing 2, 4-D + Kin not only stimulated a high accumulation of total phenolics, but also enhanced flavonoid contents. Based on the results, MD3 medium maximized the amount of these compounds in both PVP- (the highest amount for flavonoids: $24.903 \pm 7.016 \mathrm{mg} \mathrm{QE} \mathrm{g}^{-1}$ ) and PVP+ (the highest amount for total phenolics: $\left.4.303 \pm 0.449 \mathrm{mg} \mathrm{GAE} . \mathrm{g}^{-1}\right)$ media. It should be noted that along with PGRs, PVP may play a significant role in production of total phenolics. Based on the obtained results, PVP nearly improved the amounts of total phenolics and flavonoids, except for 2,4-D + Kin treatment, which accumulation of flavonoids decreased along with the presence of PVP (Fig. 2 and 3). Similarly, Rani and Nair (2006) reported that PVP has an effect on Vitix negundo L. callus organogenesis. They suggested that this might be due to PVP ability to bind phenolics and some toxic substances. In addition, high production of isoflavones and growth index were achieved in callus culture of Genista plants after addition of PVP to MS medium (Luczkeiwicz \& Glod, 2003). Previously, enhanced phenolic compounds accumulation by the combination of 2, 4-D, and Kin was also observed in Ocimum sanctum L. (Hakkim et al., 2011). Furthermore, the highest accumulation of withanolide A was showed in MS medium containing $2,4-\mathrm{D}(9.05 \mu \mathrm{M})$ and Kin $(2.32 \mu \mathrm{M})$ in cell suspension cultures of Withania somnifera (L.) Dunal (Sivanandhan et al., 2013). Also, Han et al. (2012) have obtained the highest amounts of rutin and GABA via incubation of the immobilized Morus bombycis Koidzumi cells in a full-strength MS liquid medium containing 1 $\mathrm{mg} \mathrm{l}^{-1}$ of 2,4-D and $0.1 \mathrm{mg} \mathrm{l}^{-1} \mathrm{Kin}$. Based on former reports, maximum production of phenolic compounds was obtained from the active growing cells (Fu et al., 2005; Antonigni et al., 2007). In most cases, secondary products accumulation was promoted at the end of rapid cell division in the growth cycle. However, in some of the cell culture systems, the production of secondary metabolites did not follow a parallel way with the cell growth (James et al., 2008) and the production occurred along with low growth. In the present study, as shown in Figures 1 and 2 and Table 3, an opposite relationship between growth and secondary products formation was found in NAA + TDZ and 2,4-D + Kin groups. According to our results, it can be deduced that the type of PGRs was more effective than other parameters for the production of total pheno-

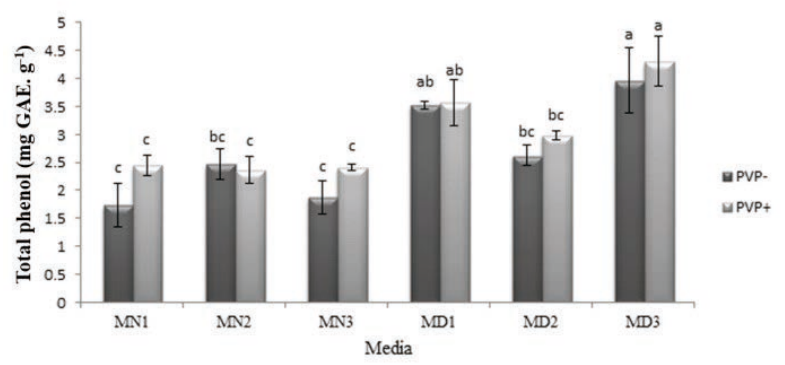

Figure 2: Content of total phenolics (mg GAE. $\mathrm{g}^{-1}$ ) in callus tissues of $S$. sahendica affected by different combinations of PGRs in MS medium (in absence and presence of PVP: PVP- and PVP +). The results are presented as means $\pm \mathrm{SE}$ $(\mathrm{n}=3)$

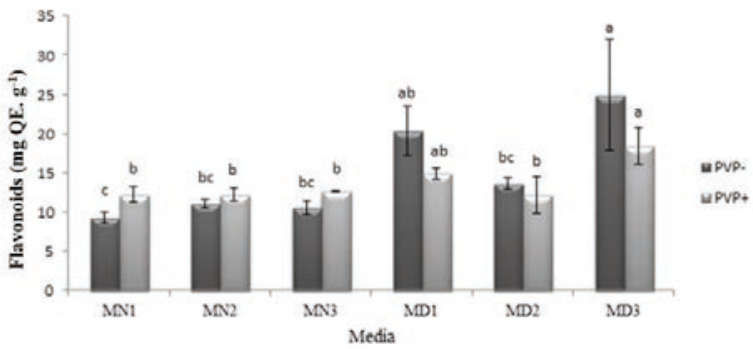

Figure 3: Content of flavonoids (mg QE. $\mathrm{g}^{-1}$ ) in callus tissues of $S$. sahendica affected by different combination of PGRs in MS medium (in absence and presence of PVP: PVP- and $\mathrm{PVP}+)$. The results are are presented as means $\pm \mathrm{SE}(\mathrm{n}=3)$ 
lic compounds. Similarly, a reverse correlation between rosmarinic acid (RA) accumulation and callus growth was reported in the callus culture of Satureja hortensis L. (Tepe \& Sokmen, 2007). Based on these results, RA accumulation and growth relationship is anthocyanin type and phenolic compound accumulation enhanced in the stationary phase of cell growth.

We suggest that the presence of $2,4-\mathrm{D}$ in media is most likely more responsible for the above-mentioned opposite relationship. As it can be seen in Table 2, application of $0.5 \mathrm{mg} \mathrm{l}^{-1}$ of both 2,4-D and Kin in medium resulted in a $100 \%$ callogenesis in presence and absence of PVP and callus formation percentage showed a significant reduction in high concentrations of these two PGRs. Actually, 2, 4-D as an auxin is commonly used as an herbicide, especially for broadleaf weeds control (WHO, 1989; US EPA, 2005b; Tomlin, 2006). It owns herbicidal and lethal effects at high concentrations, and this function probably causes the production of higher concentrations of secondary metabolites by explants in culture media.

\subsection{THE EFFECT OF SA AND PGRS ON CELL GROWTH}

The mean comparison of cells' fresh mass indicated a significant difference among the different concentrations of SA and control samples. Higher concentrations of SA reduced cell fresh mass. According to the data presented in Table 4, the highest $\left(304.67 \pm 3.48^{\mathrm{a}}\right)$ and the lowest $\left(148 \pm 3.76^{c}\right)$ amount of fresh mass in the liquid media were obtained by $100 \mu \mathrm{M}\left(1 \mathrm{mg} \mathrm{l}^{-1} 2,4-\mathrm{D}+1 \mathrm{mg} \mathrm{l}^{-1}\right.$
Kin) and $200 \mu \mathrm{M}$ of SA $\left(0.5 \mathrm{mg} \mathrm{l}^{-1} 2,4-\mathrm{D}+0.5 \mathrm{mg} \mathrm{l}^{-1} \mathrm{Kin}\right)$, respectively. The treated cells with $\mathrm{SA}$ showed a higher amount of fresh mass in $1 \mathrm{mg} \mathrm{l}^{-1} 2,4-\mathrm{D}+1 \mathrm{mg} \mathrm{l}^{-1} \mathrm{Kin}$ compared to $0.5 \mathrm{mg} \mathrm{l}^{-1} 2,4-\mathrm{D}+0.5 \mathrm{mg} \mathrm{l}^{-1} \mathrm{Kin}$ (Table 4). It should be noted that due to proper and adequate growth of callus tissues derived from MS media containing 0.5 and $1 \mathrm{mg} \mathrm{l}^{-1}$ of 2,4-D and Kin; these treatments have been chosen for further examination.

\subsection{THE EFFECT OF SA AND PGRS ON PHENO- LIC COMPOUNDS IN CELL SUSPENSION CULTURE}

According to the variance analysis and the results of phenolics and flavonoids assessment in control and treated samples with different concentrations of SA in cell suspension culture, there was a significant difference among treatments at both concentrations of 2,4-D + Kin in nodal explants of $S$. sahendica. Total phenolics and flavonoids content was enhanced by increasing the concentrations of SA, but this increase was not linear and the amount of total phenolics was reduced by high concentrations of SA. The highest and the lowest total phenolics content were obtained by $150 \mu \mathrm{M}$ SA $(2.1 \pm$ $\left.0.22 \mathrm{mg} \mathrm{GAE} \mathrm{g}^{-1}\right)$ with $0.5 \mathrm{mg} \mathrm{l}^{-1} 2,4-\mathrm{D}+0.5 \mathrm{mg} \mathrm{l}^{-1} \mathrm{Kin}$ and control treatment $\left(0.78 \pm 0.007 \mathrm{mg} \mathrm{GAE} \mathrm{g}^{-1}\right)$ with 1 $\mathrm{mg} \mathrm{l^{-1 }} 2,4-\mathrm{D}+1 \mathrm{mg} \mathrm{l}^{-1}$ Kin, respectively (Fig. 4 and 5). On the other hand, there was no significant difference among different concentrations of SA, except for the control treatment (Fig. 4). According to Table 3, the highest $\left(358.6 \pm 0.00 \mathrm{mg} \mathrm{QE} \mathrm{g}^{-1}\right)$ and the lowest $(70.88 \pm 0.47 \mathrm{mg}$ QE $\mathrm{g}^{-1}$ ) production of flavonoids were obtained by 150

Table 4: Effect of different combination of PGRs and SA on cell fresh mass in suspension cell culture of Satureja sahendica

\begin{tabular}{|c|c|c|}
\hline PGRs treatments & Elicitor concentratic & \\
\hline $2,4-\mathrm{D}+\operatorname{Kin}\left(\mathrm{mg} \mathrm{l}^{-1}\right)$ & Salicylic acid $(\mu \mathrm{M})$ & Fresh mass (mg) \\
\hline \multirow[t]{4}{*}{$0.5: 0.5$} & Control & $175 \pm 1.76^{\mathrm{b}}$ \\
\hline & 100 & $266 \pm 4.62^{\mathrm{a}}$ \\
\hline & 150 & $186.67 \pm 6.96^{\mathrm{b}}$ \\
\hline & 200 & $148 \pm 1.73 c$ \\
\hline \multirow[t]{4}{*}{$1: 1$} & Control & $185.33 \pm 2.96^{c}$ \\
\hline & 100 & $304.67 \pm 3.48^{\mathrm{a}}$ \\
\hline & 150 & $283.67 \pm 3.18^{b}$ \\
\hline & 200 & $158 \pm 4.04^{\mathrm{d}}$ \\
\hline
\end{tabular}

Different letters within the same column represent statistically significant differences among treatments at $p \leq 0.05$ 
$\mu \mathrm{M}$ of SA and control treatment with $0.5 \mathrm{mg} \mathrm{l}^{-1}(2,4-\mathrm{D}$ + Kin), respectively. No significant difference was found among different concentrations of SA in both concentrations (0.5 and $1 \mathrm{mg} \mathrm{l}^{-1}$ ) of 2,4-D + Kin (Fig. 6).

Investigation of SA effects on total phenolics and flavonoids contents in suspension culture of nodalderived callus tissues of $S$. sahendica showed that these parameters were increased by 100 to $150 \mu \mathrm{M}$ of SA and decreased by enhancement in SA concentration to 200 $\mu \mathrm{M}$. Presumably, reduction in total phenolics and flavonoids contents in $200 \mu \mathrm{M}$ of SA can be caused by the limited ability of cells in response to stresses or reduced enzymes activity. The maximum amount of phenolics and flavonoids content was obtained by 150 $\mu \mathrm{M}$ of SA and the flavonoids and total phenolics were 2 and 5 times more than the control group, respectively (with 0.5 Kin $+0.52,4-\mathrm{D}$ ). Interestingly, with a further increase in the SA concentration, not only the increasing in accumulation of total phenolics and flavonoids was not achieved, but also the accumulation process of these parameters was declined.

Similar to our results, Esmaeilzadeh Bahabadi and Rezaei (2014) using cell culture of Trigonella foenumgraecum L. showed a significant reduction in cell growth with the increasing concentrations of SA. Thus, higher concentrations of SA have a detrimental effect on plant's oxidative condition and eventually cause plant death

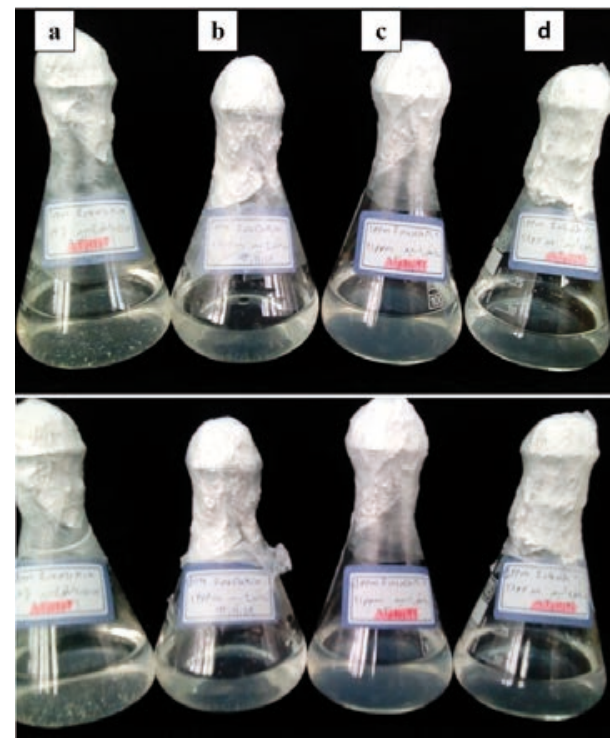

Figure 4: Comparison of total phenolics and flavonoids content after treatment with different concentrations of SA $(0,100,150$, and $200 \mu \mathrm{M}$, left to right) in cell suspension of $S$. sahendica. Upper row: Callus tissues grown on MS medium containing $1 \mathrm{mg} \mathrm{l}^{-1} 2,4-\mathrm{D}+1 \mathrm{mg} \mathrm{l}^{-1} \mathrm{Kin}$. Lower row: callus tissues grown on MS medium containing $0.5 \mathrm{mg} \mathrm{l}^{-1} 2,4-\mathrm{D}+$ $0.5 \mathrm{mg} \mathrm{l}^{-1} \mathrm{Kin}$

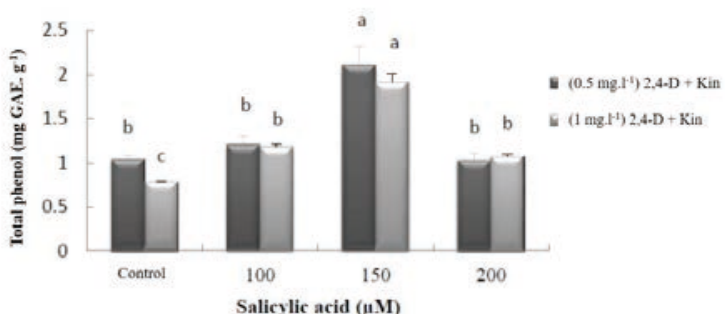

Figure 5: Content of total phenolics (mg GAE. $\mathrm{g}^{-1}$ ) in cell suspension culture of $S$. sahendica after treatment with different concentrations of SA in MS medium containing different combinations of 2, 4-D + Kin. The results are presented as means \pm SE $(n=3)$

(Kovacik, 2009). They also reported that total phenolics content was increased by $50 \mathrm{mg} \mathrm{l}^{-1} \mathrm{SA}$. Due to an inverse relationship between growth and accumulation of secondary metabolites, the inhibition of cell growth by SA might induce the synthesis of secondary metabolites. Because precursors of secondary metabolite biosynthesis originate from the primary metabolism, under severe stress the primary metabolism changes to the secondary metabolism and the necessary resources are diverted from development to defense (Harfouche et al., 2008). Moreover, total phenolics and flavonoids contents were increased by different concentrations $(0,50,100,200$, and $250 \mu \mathrm{M}$ ) of SA in Cynara scolymus L. (Samadi et al., 2014) and by the increasing concentration of SA up to $100 \mu \mathrm{M}$, total phenolics and flavonoids contents showed

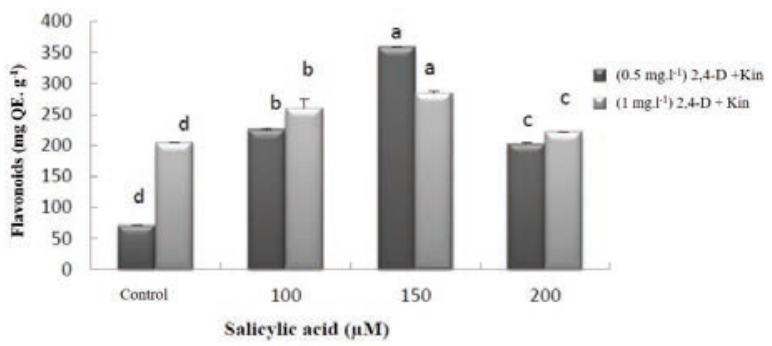

Figure 6: Content of flavonoids (mg QE. $\mathrm{g}^{-1}$ ) in cell suspension culture of $S$. sahendica after treatment with different concentrations of SA in MS medium containing different combinations of 2, 4-D + Kin. The results are presented as means \pm SE $(n=3)$ 
a significant increase. These results are in agreement with the findings of the present work. They also reported that the changes of phenylpropanoid compounds were positively correlated with phenylalanine ammonia lyase (PAL) activity, and total phenolics and flavonoids content was also increased by PAL increased activity (Samadi et al., 2014). The effects of different elicitors on polyphenols content and activity of other polyphenol-related enzymes were also studied. For instance, shikimate dehydrogenase (SDH), tyrosine ammonia lyase TAL, cinnamate4-hydroxylase $(\mathrm{C} 4 \mathrm{H})$, 4-coumarate/coenzyme A ligase (4-CL), and dihydroflavonol 4-reductase (DFR) were activated by elicitors such as SA and methyl jasmonate (Ruiz-García and Encarna Gómez-Plaza, 2013; Kim et al., 2020). Interestingly, the activity of PAL was directly related to the concentration of SA, so that the PAL activity changes were similar to total phenolics and flavonoids accumulation via increasing the amount of SA. The previous reports have suggested that the amount of phenolics and flavonoids was strongly influenced by PAL enzyme activity (Sun et al., 2012; Ruiz-García and Encarna Gómez-Plaza, 2013). SA, as a stress-inducing compound, activates the signaling pathway of PAL, subsequently, PAL results in activation of the phenylpropanoid pathway and increasing the production of phenolic compounds by increasing the transcription of specific mRNA, in which these compounds counteract the induced stress. Elicitors, such as SA and methyl jasmonate, play an important role in the signaling process which induces the biosynthesis of phenolic compounds and expression of plant defense genes (Wen et al., 2004; Wang et al., 2009). Exposure to elicitors may lead to an increase in the content of defense related compounds such as total phenolics, flavonoids and phytoalexins. This might be due to an increase in the expression levels of responsible genes for the biosynthesis of these metabolites. Similar to our results, Sadeghian et al. (2013) reported that in Satureja khuzistanica Jamzad polyphenol oxidase and superoxide dismutase enzymes activity as well as total protein contents of SA $\left(0,50,100,200\right.$, and $\left.400 \mathrm{mg} \mathrm{l}^{-1}\right)$. Moghadam et al. (2013) found that the application of SA $(125,250$, $500 \mathrm{mmol}$ ) in suspension culture of Portulaca oleracea L. hairy roots increased dopamine production with the highest amount at the concentration of $250 \mathrm{mM}$. Moreover, flavonoid content was enhanced by the application of SA $(0.05,0.5,1$, and $1.5 \mathrm{mM})$ in the suspension culture of Andrographis paniculata (Matkowski, 2008). The studies about the effect of SA concentration $(1,1.5,2 \mathrm{mM})$ on stimulating of Cicer arietinum L. immune system showed that this plant quickly responds to $1.5 \mathrm{mM}$ of SA, and polyphenol oxidase activity increases in this concentration (Rajjou et al., 2006). Despite decreasing total phenolic contents at higher concentrations, increasing above mentioned concentration $(1.5 \mathrm{mM})$ was reported. These results show that exposure to $1.5 \mathrm{mM}$ of $\mathrm{SA}$ is harmless for plants and this concentration may induce the chemical defense response. However, treatment of samples with $2 \mathrm{mM} \mathrm{SA}$ caused phytotoxicity, which in turn might lead to low production of phenolic compounds (War et al., 2011). These findings are in fair agreement with the findings of current work. Also, it has been reported that the high concentration of SA induces hypersensitivity response that leads to cell death, while low concentrations of SA induces immune response (Namadeo, 2007). Therefore, the increased production and accumulation of phenolic compounds and flavonoids which found in $S$. sahendica suspension culture can be attributed to the induceded defense responses with SA.

\section{CONCLUSION}

In the present study, the culture medium for callus induction from nodal explants of Satureja sahendica was optimized. Furthermore, the production of some secondary metabolites in the obtained callus tissues were determined. It was found that callus growth and secondary metabolites production of $S$. sahendica was strongly affected by type, combination, and different concentrations of PGRs and statistically significant differences were found between 2,4-D + Kin and NAA + TDZ treatments. Moreover, the media containing 2, 4-D + Kin stimulated the production of both total phenolics and flavonoid compounds. Along with PGRs, PVP was generally an effective component in improvement of the studied parameters. In addition, the impact of SA on the accumulation and biosynthesis of secondary metabolites by cell suspension cultures of $S$. sahendica was also investigated. Based on the obtained results, SA can be used as a stimulant to improve the amount of phenolic compounds in the cell suspension cultures of this plant under controlled conditions.

\section{AUTHOR CONTRIBUTIONS}

R.M., M.K.-N. and A.M. planned the research. All authors have read and agreed to the published version of the manuscript.

\section{ACKNOWLEDGMENTS}

The authors thank the University of Tabriz for supporting and making funds available for this work. 


\section{REFERENCES}

Ali, M., Abbasi, B. H., Ul-haq, I. (2013). Production of commercially important secondary metabolites and antioxidant activity in cell suspension cultures of Artemisia absinthium L. Industrial Crops and Products, 49, 400-406. https://doi.org/10.1016/j.indcrop.2013.05.033

Al-juboory, K. H., Skirvin, R.M., William, D.J. (1998). Callus induction and adventitious shoot regeneration of gardenia (Gardenia jasminoides Ellis) leaf explants. Scientia Horticulturae, 72(3-4), 171-178. https://doi.org/10.1016/ S0304-4238(97)00060-5

Al-Sane, K. O., Shibli, R.A., Freihat, N.M., Hammouri, M.K. (2005). Cell suspension culture and secondary metabolites production in African violet (Saintpaulia ionantha Wendl.). Jordan Journal of Agricultural Sciences, 1(1), 84-92.

Alvarez, P.S., Spollansky, T. C., Giulietti, A.M. (2000). The influence of different biotic and abiotic elicitors on the production and profile of tropane alkaloids in hairy root cultures of Brugmansia candida. Enzyme and Microbial Technology, 26(2-4), 254-258. https://doi.org/10.1016/ S0141-0229(99)00137-4

Antonigni, F., Zheng, S., Pagnucco, C., Baraldi, R., Poli, F., Biondi, S. (2007). Induction of flavonoid production by UV-B radiation in Passiflora quagrangularis callus cultures. Fitoterapia, 78(5), 345-352. https://doi.org/10.1016/j.fitote.2007.02.001

Chang, C. C., Yang, M.Y., Wen. H. M., Chern, J. C. (2002). Estimation of total flavonoid content in propolis by two complementary colorimetric methods. Journal of Food and Drug Analysis, 10(3), 178-182. https://doi.org/10.38212/22246614.2748

Dörnenburg, H., Knorr, D. (1995). Strategies for the improvement of secondary metabolite production in plant cell cultures. Enzyme and Microbial Technology, 17(8), 674-684. https://doi.org/10.1016/0141-0229(94)00108-4

Esmaeilzadeh Bahabadi, S., Rezaei, A. (2014). Increased trigonelline production by salicylic acid in fenugreek (Trigonella foenum-graecum L.) cell culture. (in Persian). Journal of Cell and Tissue, 5, 165-172.

Fu, C. X., Zhao, D.X., Huang, Y., Ma, F. S. (2005). Cellular aggregate size as the critical factor for flavonoid production by suspension cultures of Saussurea medusa. Biotechnology Letters, 27(2), 91-95. https://doi.org/10.1007/s10529-0046934-1

Ghahreman, A. (1988). Flora of Iran (in Persian). Research Institute of Forest and Rangeland, Tehran.

Ghahreman, A. (1993). Plant Systematics: Cormophytes of Iran (in Persian). Iran University Press, Tehran.

Ghotbabadi, F. S., Alizadeh, A., Zadehbagheri, M., Kamelmanesh, M. M., Shaabani, M. (2012). Phytochemical composition of the essential oil, total phenolic content, antioxidant and antimicrobial activity in Iranian Satureja sahendica Bornm. at different ontogenesis conditions. Journal of Medicinal Plants Research, 6(19), 3525-3534. https:// doi.org/10.5897/JMPR11.374

Güllüce, M., Sokmen, M., Daferera, D., Ağar, G., Özkan, H., Kartal, N., Polissiou, M., Sökmen, A., Sahin, F. (2003). In vitro antibacterial, antifungal, and antioxidant activities of the essential oil and methanol extracts of herbal parts and callus cultures of Satureja hortensis L. Journal of Agricultural and Food Chemistry, 51(14), 3958-3965. https://doi. org/10.1021/jf0340308

Hadian, J., Akramian, M., Heydarian, H., Mumivan, H., Asghari, B. (2012). Composition and in vitro antibacterial activity of essential oils from four Satureja species growing in Iran. Natural Product Research, 26(2), 98-108. https:// doi.org/10.1080/14786419.2010.534734

Hadjmohammadi, M. R., Soltani, M., Sharifi, V. (2012). Use of hollow fiber liquid phase microextraction and HPLC for extraction and determination of apigenin in human urine after consumption of Satureja sahendica Bornm. Journal of Chromatography B, 900, 85-88. https://doi.org/10.1016/j. jchromb.2012.05.022

Hakkim, F. L., Gowri-Shankar, C., Girija, S. (2007). Chemical composition and antioxidant property of holy basil (Ocimum sanctum L.) leaves stems, and inflorescence and their in vitro callus cultures. Journal of Agricultural and Food Chemistry, 55(22), 9109-9117. https://doi.org/10.1021/ jf071509h

Hakkim, F. L., Kalyani, S., Essa, M., Girija, S. Song, H. (2011). Production of rosmarinic acid in Ocimum sanctum (L.) cell suspension cultures by the influence of growth regulators. International Journal of Biological and Medical Research, 2(4), 1158-1161.

Han, K.L., Lee, Y., Song, J. H., Hwang, Y. S., Lee, W. S., Kim, M. W., Kim, S. H. (2012). Enhanced production and secretion of rutin and GABA in immobilized cells of mulberry tree (Morus bombycis K.). Plant Cell, Tissue and Organ Culture, 108(3), 513-20. https://doi.org/10.1007/s11240-011-00282

Harfouche, A. L., Rugini, E., Mencarelli, F., Botondi, R., Muleo, R. (2008). Salicylic acid induces $\mathrm{H}_{2} \mathrm{O}_{2}$ production and endochitinase gene expression but not ethylene biosynthesis in Castanea sativa in vitro model system. Journal of Plant Physiology, 165(7), 734-744. https://doi.org/10.1016/j. jplph.2007.03.010

Hassanpouraghdam, M. B., Safi-Shalamzari, M., Azami, M. A., Mohajjel-Shoja, A. (2009). $\gamma$-terpinene and carvacrol rich volatile oil of Satureja sahendica Bornm. from Maragheh district in Northwest Iran. Chemija, 20(3), 186-189.

James, J. T., Meyer, R., Dubery, I. A. (2008). Characterization of two phenotypes of Centella asiatica in Southern Africa through the composition of four triterpenoids in callus, cell suspensions and leaves. Plant Cell, Tissue and Organ Culture, 94(1), 91-99. https://doi.org/10.1007/s11240-0089391-z

Jamzad, Z. (1996). Satureja rechingeri (Labiatae): A new stream. Species from Iran. (pp. 75-7). Annalen des Naturhistorischen Museums in Wien.

Jeong, G. T., Woo, J. C., Park, D. H. (2007). Effect of plant growth regulators on growth and biosynthesis of phenolic compounds in genetically transformed hairy roots of Panax ginseng C. A. Meyer. Biotechnology and Bioprocess Engineering, 12(2), 86-9. https://doi.org/10.1007/BF03028631

Johnson, M., Wesely, E. G., Kavitha, M. S., Uma, V. (2011). Antibacterial activity of leaves and inter-nodal callus extracts of Mentha arvensis L. Asian Pacific Journal of Tropical 
Medicine, 4(3), 196-200. https://doi.org/10.1016/S19957645(11)60068-0

Khosroushahi, A. Y., Valizadeh, M., Gasempour, A., Khosroushahi, M., Naghdibadi, H., Dadpour, M. R., Omidi, Y. (2006). Improved taxol production by combination of inducing factor in suspension culture of Taxus baccata. Cell Biology International, 30(3), 262-269. https://doi. org/10.1016/j.cellbi.2005.11.004

Kim, N. S., Jung, D. H., Jung, C. R., Jeon, K. S., Park, H. W., \& Park, S. U. (2020). Improvement of phenylpropanoid production with elicitor treatments in Pimpinella brachycarpa Nakai. Horticulturae, 6(4), 108. https://doi.org/10.3390/ horticulturae 6040108

Kovacik, J., Backor, M., Strnad, M., Repcak, M. (2009). Salicylic acid-induced changes to growth and phenolic metabolism in Matricaria chamomilla plants. Plant Cell Reports, 28(1), 135-143. https://doi.org/10.1007/s00299-008-0627-5

Leyser, O., Day, S. (2003). Mechanism in plant development, Oxford, UK: Blackwell Science Ltd, ISBN: 978-0-86542742-6.

Luczkeiwicz, M., Glod, D. (2003). Callus cultures of Genista plants- in vitro material producing high amounts of isoflavones of phytoestrogenic activity. Plant Science, 165(5), 1101-1108. https://doi.org/10.1016/S01689452(03)00305-4

Matkowski, A. (2008). Plant in vitro culture for the production of antioxidants - A review. Biotechnology Advances, 26(6), 548-560. https://doi.org/10.1016/j.biotechadv.2008.07.001

Mendhulkar, V. D., Moinuddin, M., Vakil, A. (2013). Elicitation of flavonoids by salicylic acid and Penicillium expansum in Andrographis paniculata (Burm. f.) Nees. cell culture. Research in Biotechnology, 4(2), 1-9.

Moghadam, Y. A., Piri, K. H., Bahramnejad, B., \& Habibi, P. (2013). Methyl jasmonate and salicylic acid effects on the dopamine production in hairy cultures of Portulaca oleracea (purslan). Bulletin of Environment, Pharmacology and Life Sciences, 2(6), 89-94.

Mozaffarian, V. (1993). A dictionary of Iranian plant names (pp. 482-483) Farhang Moaser Publication, Tehran, Iran.

Mozaffarian, V. (1996). A dictionary of Iranian plant names. Farhang Moaser Publication, Tehran, Iran.

Murashige, T., Skoog, E. (1962). A revised medium for rapid growth and bioassays with tobacco tissue cultures. Physiologia Plantarum, 15(3), 473-497. https://doi. org/10.1111/j.1399-3054.1962.tb08052.x

Murthy, B. N. S., Murch, S. J. Saxena, P. K. (1998). Thidiazuron: A potent regulator of in vitro plant morphogenesis. In Vitro Cellular \& Developmental Biology-Plant, 34(4), 267-275. https://doi.org/10.1007/BF02822732

Namadeo, A. G. (2007). Plant cell elicitation for production of secondary metabolites- A review. Pharmacognosy Reviews, 1(1), 154-160.

Neumann, K. H., Kumar, A., Imani, J. (2009). Plant cell and tissue culture. A tool in biotechnology (pp. 333). SpringerVerlag Berlin Heidelberg.

Ogita, S., Sasamoto, H., Yeung, E. C., \& Thorpe, T. A. (2001). The effects of glutamine of the maintenance of embryogenic cultures of Cryptomeria japonica. In Vitro Cellular \&
Developmental Biology-Plant, 37(2), 268-273. https://doi. org/10.1007/s11627-001-0048-4

Pourebad, N., Motafakkerazad, R., Kosari-Nasab, M., FarsadAkhtar, N., Movafeghi, A. (2015). The influence of TDZ concentrations on in vitro growth and production of secondary metabolites by the shoot and callus culture of Lallemantia iberica. Plant Cell, Tissue and Organ Culture, 122(2), 331-339. https://doi.org/10.1007/s11240-015-0769-4

Rajjou, L., Belghazi, M., Huguet. R., Robin, C., Moreau, A., Job, C. (2006). Proteomic investigation of the effect of salicylic acid on Arabidopsis seed germination and establishment of early defense mechanisms. Plant Physiology, 141(3), 910-23. https://doi.org/10.1104/pp.106.082057

Rani, D. N., Nair, G. M. (2006). Effects of plant growth regulators on high frequency shoot multiplication and callus regeneration of an important Indian medicinal plant, Nirgundi (Vitix negundo L.). In Vitro Cellular and Developmental Biology-Plant, 42(1), 69-73. https://doi.org/10.1079/ IVP2005727

Ravishandera, G. A., Bhyalakshmi, N., Ramachandra Rao, S. (1999). Production of food additive. Biotechnology: Secondary metabolites (pp. 89-110). New Dehli: Oxford IBH.

Rechinger, K. H. (1982). Satureja in Flora Iranica (pp. 495-504). Akademische Druck-u. Verlagsanstalt, Graz.

Ruiz-García, Y., \& Gómez-Plaza, E. (2013). Elicitors: a tool for improving fruit phenolic content. Agriculture, 3(1), 33-52. https://doi.org/10.3390/agriculture3010033

Sadeghian, F., Hadian, J., Hadavi, M., Mohamadi, A., Ghorbanpour, M., Ghafarzadegan, R. (2013). Effects of exogenous salicylic acid application on growth, metabolic activities and essential oil composition of Satureja khuzistanica Jamzad. Journal of Medicinal Plants, 3(47), 70-82.

Saeidnia, S., Nourbakhsh, M. S., Gohari, A. R., Davood, A. (2011). Isolation and identification of the main compounds of Satureja sahendica Bornm. Australian Journal of Basic and Applied Sciences, 5(6), 1450-1453. https://doi. org/10.1021/jf303755w

Samadi, S., Ghasemnezhad, A., Alizadeh, M. (2014). Investigation on phenylalanine ammonia-lyase activity of artichoke (Cynara scolymus L.) affected by methyl jasmonate and salicylic acid in in-vitro conditions (in Persian). Journal of Plant Production Research, 21, 135-148.

Saxena, P. K., \& Gill, R. (1986). Removal of browning and growth enhancement by polyvinylpolypyrrolidone in protoplast cultures of Cyamopsis tetragonoloba L. Biologia Plantarum, 28(4), 313-315. https://doi.org/10.1007/BF02902302

Saxena, S., \& Dhawan, V. (1999). Regeneration and large-scale propagation of bamboo (Dendrocalamus strictus Nees) through somatic embryogenesis. Plant Cell Reports, 18(5), 438-443. https://doi.org/10.1007/s002990050600

Sefidkon, F., Jamzad, Z. Mirza, M. (2004). Chemical variation in the essential oil of Satureja sahendica from Iran. Food Chemistry, 88(3), 325-328. https://doi.org/10.1016/j.foodchem.2003.12.044

Shilpashree, H., Rai, R. (2009). Effects of growth regulators on in vitro plant regeneration and flavonoid production in $\mathrm{Hy}$ pericum mysorense. International Journal of Integrative Biology, 8(1), 43-49.

Singleton, V. L., Orthofer, R., Lamuela-Raventos, R. M. (1999). 
Analysis of total phenols and other oxidation substrates and oxidants by means of Folin-Ciocalteu reagent. Methods in Enzymology, 299, 152-178.

Sivanandhan, G., Kapil Dev, G., Jeyaraj, M., Rajesh, M., Muthuselvam, M., Selvaraj, N., Manickavasagam, M., Ganapathi, A. (2013). A promising approach on biomass accumulation and withanolides production in cell suspension culture of Withania somnifera (L.) Dunal. Protoplasma, 250(4), 885-898. https://doi.org/10.1007/s00709-0120471-x

Sun, Z., Hou, S., Yang, W., \& Han, Y. (2012). Exogenous application of salicylic acid enhanced the rutin accumulation and influenced the expression patterns of rutin biosynthesis related genes in Fagopyrum tartaricum Gaertn leaves. Plant Growth Regulation, 68(1), 9-15. https://doi.org/10.1007/ s10725-012-9688-0

Tarigholizadeh, S., Motafakkerazad, R., Kosari-Nasab, M., Movafeghi, A. (2015). Callus medium improvement for Satureja sahendica as an important medicinal plant. International Journal of Integrative Biology, 16(1), 13-18.

Taveira, M., Ferreres, F., Pereira, M. D., Sousa, C., Andrade, B. P., Martins, A., Pereira, A. J., Valentao, P. (2010). In vitro culture of Brassica oleracea L.var. costata DC: potential plant bioreactor for antioxidant phenolic compounds. Journal of Agricultural and Food Chemistry, 57(4), $1247-$ 1252. https://doi.org/10.1021/jf803496x

Tepe, B., Sokmen, A. (2007). Production and optimization of rosmarinic acid by Satureja hortensis L. callus cultures. Natural Product Research, 21(13), 1133-1144. https://doi. org/10.1080/14786410601130737

Thiruvengadam, M., Chung, I. M. (2015). Phenolic compound production and biological activities from in vitro regenerated plants of gherkin (Cucumis anguria L.). Electronic Journal of Biotechnology, 18(4), 295-301. https://doi. org/10.1016/j.ejbt.2015.05.005

Tomlin, C. D. S. (2006). The Pesticide Manual: A World Compendium. 14th ed. British Crop Protection Council: Surrey, UK.

United States Environmental Protection Agency (US EPA). Reregistration eligibility decision for 2,4-D. EPA 738-R-05002; June 2005b.

Vlot, A. C., Klessig, D. F., Park, S. W. (2008). Systemic acquired resistance: the elusive signal(s). Current Opinion in Plant Biology, 11(4), 436-442. https://doi.org/10.1016/j. pbi.2008.05.003

Walla Abdelazeez, M. A., Khusnetdinova Landysh, Z., Timofeeva Olga, A. (2017). Effect of different plant growth regulators on the in vitro induction and maintenance of callus from different explants of Hyoscyamus muticus L. Journal of Applied Environmental and Biological Sciences, 7(3), 27-35. https://doi.org/10.17816/snv201873101

Wang, K., Jin, P., Cao, S., Shang, H., Yang, Z., Zheng, Y. (2009). Methyl jasmonate reduces decay and enhances antioxidant capacity in Chinese bayberries. Journal of Agricultural and Food Chemistry, 57(13), 5809-5850. https://doi. org/10.1021/jf900914a

Wang, Y., Yuan, Y., Wn, J. (2004). Induction studies of methyl jasmonate and salicylic acid on taxane production in suspension cultures of Taxus chinensis var. mairei. Biochemical Engineering Journal, 19(3), 259-265. https://doi. org/10.1016/j.bej.2004.02.006

War, A. R., Paulraj, M. G., War, M. Y., Ignacimuthu S. (2011). Jasmonic acid-mediated induced resistance in groundnut (Arachis hypogaea L.) against Helicoverpa armigera (Hubner) (Lepidoptera: Noctuidae). Journal of Plant Growth Regulation, 30(4), 512-523. https://doi.org/10.1007/s00344011-9213-0

Wen, P. F., Chen, J. Y., Kong, W. F., Pan, Q. H., Wan, S. B., Huang, W. D. (2004). Salicylic acid induced the expression of phenylalanine ammonia-lyase gene in grape berry. Plant Science, 169(5), 928-934. https://doi.org/10.1016/j.plantsci.2005.06.011

World Health Organization (WHO). Environmental Health Criteria 84, Environmental aspects - 2,4-dichlorophenoxyacetic acid (2,4-D); International Programs on Chemical Safety. World Health Organization: Geneva, Switzerland; 1989.

Zhong, J. J., Bai, Y., Wang, S. J. (1996). Effects of plant growth regulators on cell growth and ginsenoside saponin production by suspension cultures of Panax quinquefolium. Journal of Biotechnology, 45(3), 227-234. https://doi. org/10.1016/0168-1656(95)00170-0 